\title{
Genetic variability, Heritability and Genetic advance in Boro Rice (Oryza sativa L.) germplasm
}

\author{
K. Rajendra Prasad ${ }^{1 *}$, K.V. Radha Krishna ${ }^{1}$, M.H.V. Bhave ${ }^{2}$ and L.V. Subba Rao ${ }^{3}$ \\ ${ }^{1}$ Department of Genetics and Plant Breeding, College of Agriculture, PJTS Agricultural \\ University, Rajendranagar, Hyderabad-500030, Telangana, India \\ ${ }^{2}$ Department of Statistics and Mathematics, College of Agriculture, PJTS Agricultural \\ University, Rajendranagar, Hyderabad-500030, Telangana, India \\ ${ }^{3}$ Indian Institute of Rice Research, Rajendranagar, Hyderabad-500030, Telangana, India \\ *Corresponding author
}

\begin{tabular}{|l|}
\hline Ke y w o r d s \\
Genetic variability, \\
Heritability, \\
Genetic advance, \\
Yield, Yield \\
attributes and Rice. \\
\hline Article Info \\
\hline Accepted: \\
12 March 2017 \\
Available Online: \\
10 April 2017 \\
\hline
\end{tabular}

\section{Introduction}

The boro rice is commonly known as winter rice. The term boro is Bengali originated from the Sanskrit word "Boro" which refers to a cultivation from Nov-May under irrigated condition. Boro rice cultivation is relatively a new phenomenon in Bihar agriculture, where rice is being grown since time immemorial, during both kharif and rabi seasons. The cultivation of rice during rabi crop season (Nov-May) was unknown probably till the new rice strains through Bangladesh refugees were introduced in these parts of India. Boro rice has traditionally been cultivated in the river basins, deltas, chaurs or saucer shaped depressions, where water accumulates during the monsoons but cannot be drained, thus providing ideal settings for boro rice cultivation during winter season. Although, boro rice cultivation has been an old practice in deep water areas, it is only recently that it has emerged as a major breakthrough in enhancing rice productivity, not only in traditional, but also in non-traditional boro rice areas with assured irrigation and modern 
inputs. The credit primarily goes to the farmers' own initiatives in adopting its cultivation in a big way. But proper research inputs have not been fully exploited by the farmers. It is therefore worthwhile to examine the current scenario and analyse the future concerns. With the increased availability of irrigation facilities, boro rice technology has also moved to non-traditional flood-free irrigated areas. Northeastern region of Bihar also known, as 'Kosi' region comprises of Saharsa, Madhepura, Supaul, Purnea, Katihar, Darbhanga, Madhubani, and Khagaria districts, this region is characterized by high water level and during good monsoon years, large tracts of land become unsuitable for traditional rabi crop due to water logging and flooding from Kosi and its many tributaries. Wheat cultivation in this region is a remote possibility due to water stagnation, thus rice is the only option left with the farmers. Boro rice has come as a boon to the farmers of this region, but it has become popular only recently with the introduction of cold tolerant rice varieties. Therefore, the present investigation was undertaken to assess the nature and magnitude of genetic variability, heritability and genetic advance among the genotypes for further utilization in breeding programmes.

\section{Materials and Methods}

Fifty genotypes of boro rice were grown in a randomized complete block design with three replications at the Directorate of Rice Research Farm, ICRISAT Campus, Patancheru, Hyderabad during Rabi 2013-14. Each entry was sown in six rows of $6 \mathrm{~m}$ length at spacing of $20 \mathrm{~cm}$ between rows and $30 \mathrm{~cm}$ between plants. Crop was raised following recommended package of practices. Observations were recorded on five randomly tagged plants of each genotype per replication. Data were recorded on 10 quantitative characters which includes Days to $50 \%$ Flowering, Plant Height $(\mathrm{cm})$, Number of tillers/ plant, Number of productive tillers/plant,Panicle length $(\mathrm{cm})$, Number of filled grains/panicle, Number of unfilled grains/panicle, Days to maturity, Grain yield/plant(g) and 1000-grain weight(g). Analysis of variance was done based on RBD (Panse and Sukhatme, 1961) for each of the characters separately. The phenotypic and genotypic coefficient of variance, heritability in broad sense (Burton and Devane, 1953) and Genetic advance was estimated (Allard, 1960).

\section{Results and Discussion}

The analysis of variance indicated the existence of highly significant differences among genotypes for all the characters studied (Table 1) (Shivani and Sree Rama Reddy, 2000). This indicated presence of high variability among the genotypes, which provides ample scope for selection for different quantitative characters for rice improvement. Thus the primary objective of germplasm conservation is to collect and preserve the genetic variability in indigenous collection of crop species to make it available to present and future generations (Sao, 2002). A wide range of variation was observed in the rice germplasm for the yield and other quantitative characters (Table 2). Coefficients of variation studies indicated that the estimates of PCV were slightly higher than the corresponding GCV (Fig. 1) estimates for Days to $50 \%$ flowering, plant height, number of tillers/ plant, number of productive tillers/plant, panicle length, number of filled grains/panicle, number of unfilled grains/panicle, days to maturity, grain yield/plant and 1000 grain weight indicating that the characters were less influenced by the environment (Gannamani, 2001). Therefore, selection on the basis of phenotype alone can be effective for the improvement of these traits. The characters like Number of unfilled 
grains/panicle (45.58 and 43.25), Grain yield/plant (28.40 and 26.31), Number of filled grains/panicle (28.40 and 26.31) and1000 grain weight (20.69 and 19.34) showed high PCV and GCV estimates (Sinha et al., 2004) also recorded similar observations. Low PCV and GCV estimates were obtained for days to $50 \%$ flowering (8.160 and 8.064), panicle length (8.195 and 6.320 ) and days to maturity (6.45 and 6.34).

The estimates of heritability act as predictive instrument in expressing the reliability of phenotypic value (Ashvani et al., 1997). Therefore, high heritability helps in effective selection for a particular character. In the present study, all the characters exhibited high heritability, which ranged from $97.4 \%$ to $57.5 \%$, among them Days to $50 \%$ flowering $(97.40 \%)$ has highest heritability followed by Days to maturity (96.7\%), Number of filled grains/panicle (96.5), Number of unfilled grains/panicle (90.1) (Table 2 and Fig. 2).

Based upon variability and heritability estimates, it could be concluded that improvement by direct selection in rice is possible for traits like plant height, number of tillers per plant, number of productive tillers per plant, number of filled grains per panicle, number of unfilled grains per panicle, 1000grain weight, grain yield per plant. The genetic advance is a useful indicator of the progress that can be expected as a result of exercising selection on the pertinent population (Vanniarajan et al., 1996). The genetic advance expressed as a percentage of mean ranged from 84.5-10.4 and the important characters such as Number of filled grains/panicle (56.41\%), Number of unfilled grains/panicle $(84.56 \%)$, Grain yield/plant $(50.20 \%)$ and 1000 -grain weight $(37.24 \%)$ recorded higher estimates.

Table.1 ANOVA for yield and yield contributing characters in bororice genotypes

\begin{tabular}{|c|l|c|c|c|}
\hline \multirow{2}{*}{ S.No. } & \multirow{2}{*}{ Character } & \multicolumn{2}{|c|}{ Mean sum of squares } \\
\cline { 2 - 5 } & & $\begin{array}{c}\text { Replications } \\
\text { (d.f.=2) }\end{array}$ & $\begin{array}{c}\text { Treatments } \\
\text { (d.f.=49) }\end{array}$ & $\begin{array}{c}\text { Error } \\
\text { (d.f.=98) }\end{array}$ \\
\hline 1 & Days to 50\% Flowering & 1.94 & $224.03^{* *}$ & 1.96 \\
\hline 2 & Plant Height (cm) & 0.848 & $485.15^{* *}$ & 28.28 \\
\hline 3 & No. of tillers/ plant & 0.032 & $15.71^{* *}$ & 1.86 \\
\hline 4 & $\begin{array}{l}\text { No. of productive } \\
\text { tillers/plant }\end{array}$ & 1.425 & $8.18^{* *}$ & 1.14 \\
\hline 5 & Panicle length(cm) & 2.033 & $8.16^{* *}$ & 1.51 \\
\hline 6 & No. of filled grains/panicle & 1.334 & $6981.85^{* *}$ & 82.76 \\
\hline 7 & $\begin{array}{l}\text { No. of unfilled } \\
\text { grains/panicle }\end{array}$ & 5.316 & $158.25^{* *}$ & 5.61 \\
\hline 8 & Days to maturity & 0.727 & $229.54^{* *}$ & 2.57 \\
\hline 9 & Grain yield/plant(g) & 0.161 & $27.89^{* *}$ & 1.45 \\
\hline 10 & 1000 grain weight(g) & 1.946 & $47.99^{* *}$ & 2.20 \\
\hline$* *$ Significant at 1\% level * Significant at $5 \%$ level & & \\
\hline
\end{tabular}


Table.2 Estimates of variability, heritability, genetic advance and genetic advance as per cent of mean in bororice genotypes

\begin{tabular}{|l|c|c|c|c|c|c|}
\hline \multicolumn{1}{|c|}{ Characters } & $\begin{array}{c}\text { Phenotypic } \\
\text { Variance }\end{array}$ & $\begin{array}{c}\text { Genotypic } \\
\text { Variance }\end{array}$ & $\begin{array}{c}\text { PCV } \\
\text { (\%) }\end{array}$ & $\begin{array}{c}\text { GCV } \\
\text { (\%) }\end{array}$ & $\begin{array}{c}\text { Heritability } \\
\text { in broad } \\
\text { sense(h) } \\
\text { (\%) }\end{array}$ & $\begin{array}{c}\text { Gen. Adv as } \\
\text { per cent of } \\
\text { Mean } \\
\text { (at 5\%) }\end{array}$ \\
\hline $\begin{array}{l}\text { Days to 50\% } \\
\text { Flowering }\end{array}$ & 75.984 & 74.023 & 8.160 & 8.054 & 97.40 & 16.376 \\
\hline $\begin{array}{l}\text { Plant Height } \\
\text { (cm) }\end{array}$ & 180.574 & 152.288 & 14.204 & 13.044 & 84.30 & 24.676 \\
\hline $\begin{array}{l}\text { No. of tillers/ } \\
\text { plant }\end{array}$ & 6.482 & 4.618 & 19.301 & 16.290 & 71.20 & 28.323 \\
\hline $\begin{array}{l}\text { No. of } \\
\text { productive } \\
\text { tillers/plant }\end{array}$ & 3.491 & 2.345 & 20.091 & 16.468 & 67.20 & 27.808 \\
\hline $\begin{array}{l}\text { Panicle } \\
\text { length(cm) }\end{array}$ & 3.730 & 2.218 & 8.195 & 6.320 & 59.50 & 10.041 \\
\hline $\begin{array}{l}\text { No. of filled } \\
\text { grains/panicle }\end{array}$ & 2382.463 & 2299.696 & 28.373 & 27.876 & 96.50 & 56.418 \\
\hline $\begin{array}{l}\text { No. of unfilled } \\
\text { grains/panicle }\end{array}$ & 56.495 & 50.879 & 45.584 & 43.259 & 90.10 & 84.568 \\
\hline $\begin{array}{l}\text { Days to } \\
\text { maturity }\end{array}$ & 78.229 & 75.659 & 6.451 & 6.344 & 96.70 & 12.852 \\
\hline $\begin{array}{l}\text { Grain } \\
\text { yield/plant(g) }\end{array}$ & 10.271 & 8.813 & 28.405 & 26.312 & 85.80 & 50.209 \\
\hline $\begin{array}{l}\text { 1000 grain } \\
\text { weight(g) }\end{array}$ & 17.469 & 15.264 & 20.694 & 19.344 & 87.40 & 37.248 \\
\hline
\end{tabular}

Fig.1 Graphical representation of PCV and GCV

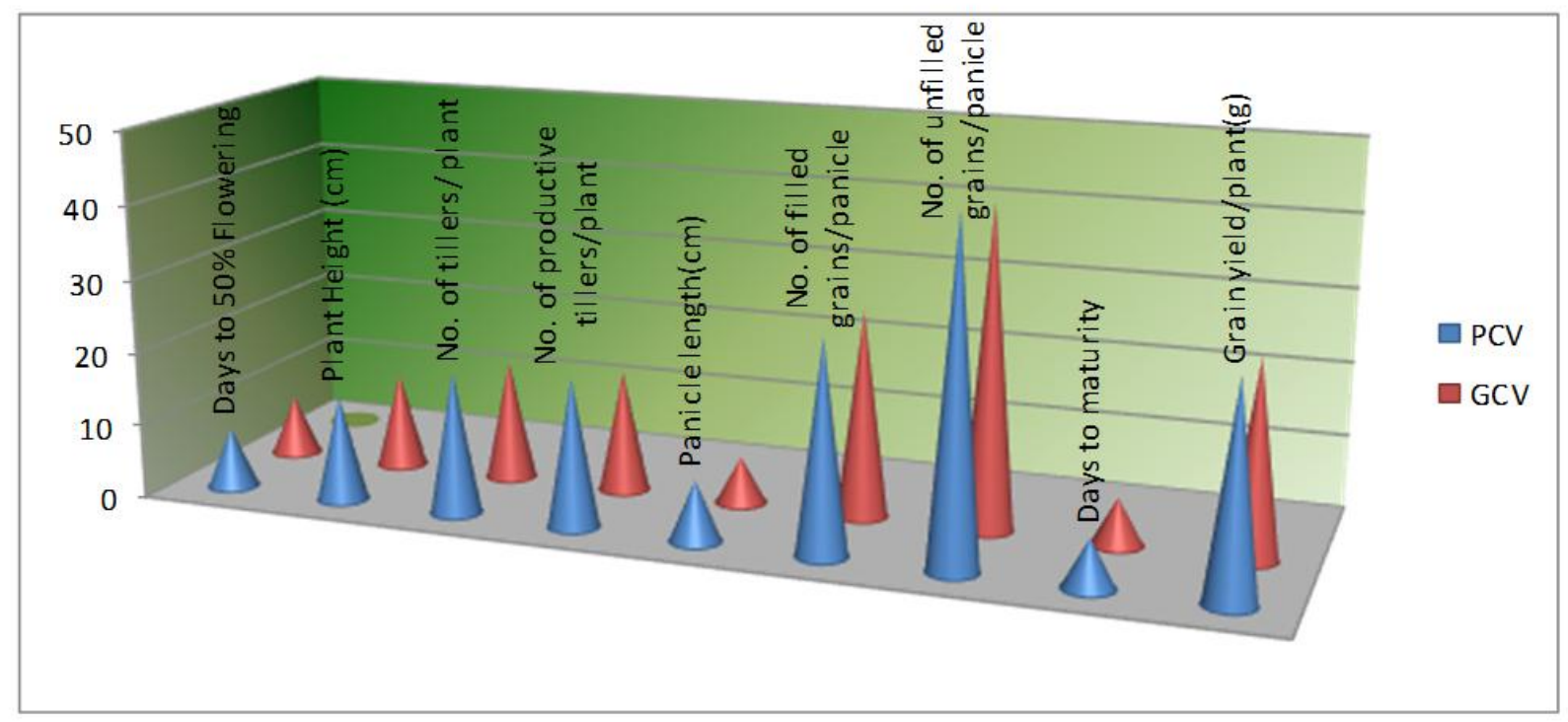


Fig.2 Graphical representation of h2 and genetic advance (5\%)

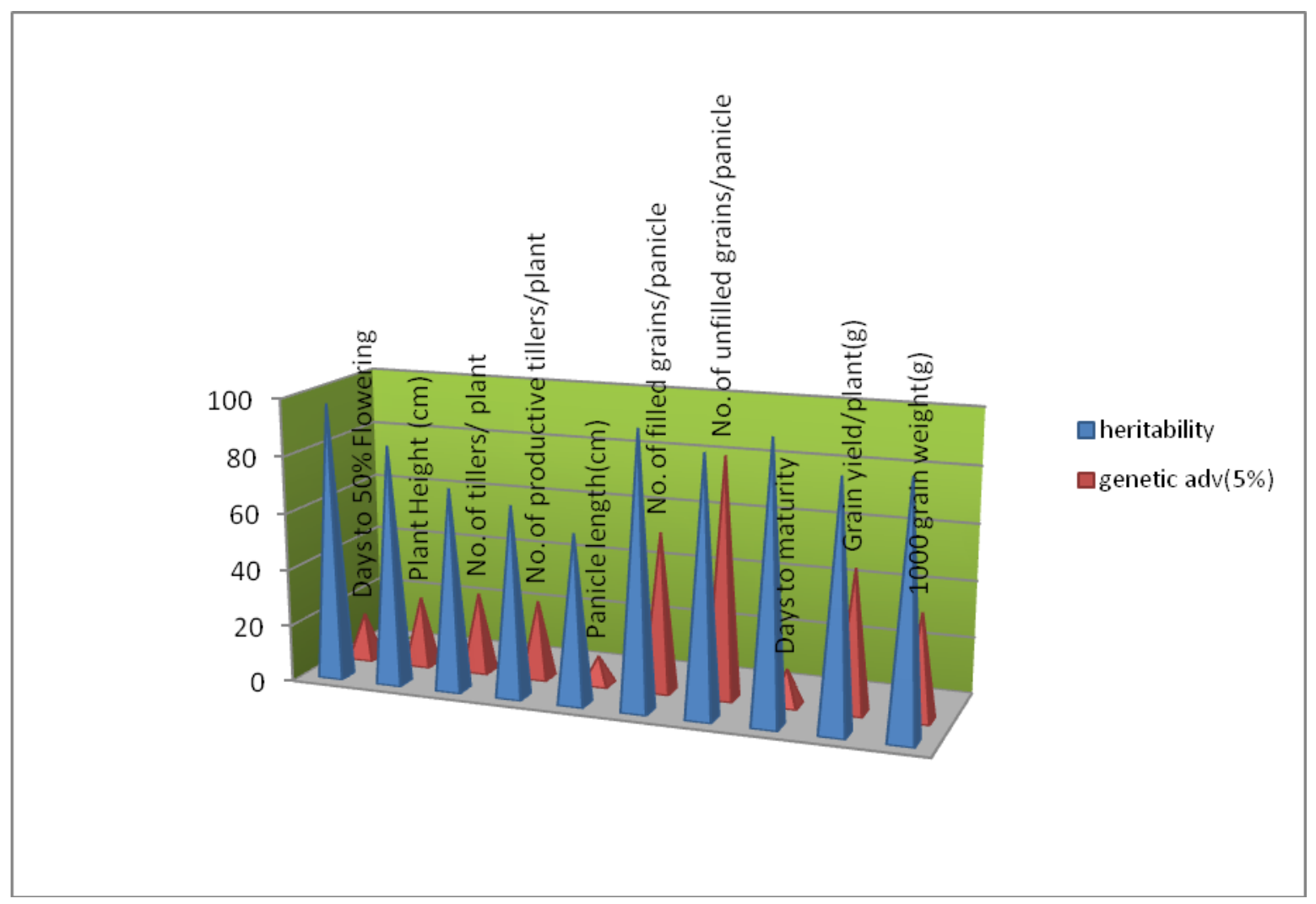

In general, the character that shows high heritability with high genetic advance are controlled by additive gene action (Patil et al., 2003) and can be improved through simple or progeny selection methods. Selection for the traits having high heritability coupled with high genetic advance is likely to accumulate more additive genes leading to further improvement of their performance (Johnson et al., 1955). The characters showing high heritability along with moderate or low genetic advance can be improved by intermating superior genotypes of segregating population developed from combination breeding (Samadia, 2005).

In conclusion, high heritability coupled with high genetic advance as percent of mean was observed for plant height, number of tillers per plant, number of productive tillers per plant, number of filled grains per panicle, number of unfilled grains per panicle, 1000- grain weight, grain yield per plant. Which indicated that these traits were controlled by additive type of gene action in the inheritance of these characters, these characters can be further improved by following simple selection procedure. The high estimates of heritability coupled with low genetic advance as percent of mean for days to $50 \%$ flowering and days to maturity indicated the presence of non-additive gene effects, in addition to influence of environment to some extent. These traits can be improved by intermating superior genotypes of segregating population developed from combination breeding.

\section{References}

Allard, R.W. 1960. Principles of Plant Breeding. Publishers by John Wiley and Sons Inc., New York, USA. 485 Pp.

Burton, G. W and Devane, E. W. (1953). 
Estimating heritability in tall fescue (Festuca arundinacea) from replicated clonal material. Agronomy Journal. 45: 478-481

Gannamani, N. (2001). Study of heterosis and combining ability by utilizing cytoplasmic genetic male sterility andfertility restoration system in rice (Oryzasativa L.), M. Sc. (Ag.) Thesis, GAU, Raipur.

Johnson, H. W., Robinson, H. F and Comstock, R. E. 1955. Estimates of genetic and environmental variability in soybean. Agronomy Journal. 47 (7): 314-318.

Panse, V. G. and Sukhatme, P. V. (1961). Statistical methods for agricultural workers. 2nd Edn ICAR, New Delhi. 361.

Panwar, Ashvani, R. P. S. R. K. Sharma, Arya, K. P. S and Panwar, A. (1997). Genetic variability and interrelationship in rice (Oryza sativa L.), Advances in Plant SciencesAdvances in Plant Sciences, 10(1): 29-32.

Patil P.V, Sarawgi A.K and Shrivastava M.N (2003). Genetic analysis of yield and quality traits in traditional aromatic accessions of rice. J. Maharashtra Agric. Univ. 28(3): 255-258.

Samadia D.K (2005). Genetic variability studies in Lasora (CordiamyxaRoxb.). Indian Journal of Plant Genetic Resources. 18(3): 236-240.

Sao, A. (2002) Studies on combining ability and heterosis in F1 rice hybrids using cytoplasmic male sterile lines,M. Sc. (Ag.) Thesis, IGAU, Raipur

Shivani, D. and Sree Rama Reddy, N. (2000).Variability, heritability and genetic advance for morphological and physiological traits in certain rice hybrids. Oryza, 37(3): 231-233.

Sinha S.K, Tripathi A.K and Bisen U.K. (2004). Study of genetic variability and correlation coefficient analysis in midland races of rice. Ann. Agric. Res. 25(1): 1-3

Vanniarajan, C., P. Rangasamy, J. Ramalingam, N. Nadarajan, and Arumugampillai. (1996). Studies on genetic variability in hybrid rice derivatives. Crop Research. 12(1):2427.

\section{How to cite this article:}

Rajendra Prasad, K., K.V. Radha Krishna, M.H.V. Bhave and Subba Rao, L.V. 2017. Genetic variability, Heritability and Genetic advance in Boro Rice (Oryza sativa L.) germplasm. Int.J.Curr.Microbiol.App.Sci. 6(4): 1261-1266. doi: https://doi.org/10.20546/ijcmas.2017.604.153 